\title{
ECOPRINT TRAINING FOR WOMEN EMPOWERMENT IN NGEMBAT SUB-VILLAGE, MOJOKERTO
}

\author{
Aniendya Christianna ${ }^{1}$, Heru Dwi Waluyanto ${ }^{2}$, Ani W. Suhartono ${ }^{4}$ \\ 1,2,3,4 Visual Communication Design Faculty of Art and Design, Petra Christian University, \\ Jl. Siwalankerto 121-131, Surabaya 60236, Indonesia \\ * Corresponding authors; E-mail: aniendya@petra.ac.id
}

\begin{abstract}
The number of women in Ngembat sub-village is quite large, both from adolescence to the elderly, but most of them are only housewives who are not economically productive. Everything depends on the husband who works as a farm laborer and builder. Women in Ngembat sub-village have a lot of free time that can be used for productive activities. The ecoprint training held during the Community Outreach Program (COP) is the development of DKV 4 courses that implement creative-sociopreneurship learning. This subject emphasizes the aspects of entrepreneurship in the field of creative industries by utilizing local strengths. Natural resources that exist around Ngembat sub-village can be utilized as products of economic value. Abundant teak leaves due to the vast size of teak forests can be a source of income for women on the sidelines of carrying out their domestic duties in the household. Free time while waiting for children to come home from school and their husbands from work can be used to empower themselves by producing creative products and economic value. Thus, not only does women's knowledge and skills improve, but the family economy can also improve
\end{abstract}

Keywords: Women empowerment, Ecoprinting, Creative-Sociopreneurship.

\begin{abstract}
Abstrak: Jumlah perempuan di Ngembat sub-village cukup banyak, baik dari usia remaja sampai dengan ibu rumah tangga, tetapi sebagian besar dari mereka hanya ibu rumah tangga yang tidak produktif secara ekonomi. Semuanya bergantung pada suami yang bekerja sebagai buruh tani dan tukang bangunan. Perempuan di Ngembat sub-village memiliki banyak waktu luang yang dapat dimanfaatkan untuk kegiatan yang produktif. Pelatihan ecoprint yang diadakan dalam masa Community Outreach Program (COP) merupakan pengembangan mata kuliah DKV 4 yang mengimplementasikan pembelajaran creative-sociopreneurship. Mata kuliah ini mengedepankan aspek kewirausahaan dibidang industri kreatif dengan memanfaatkan keunggulan lokal. Sumber daya alam yang ada disekitar Ngembat sub-village dapat dimanfaatkan menjadi produk yang bernilai ekonomi. Daun jati yang melimpah karena luasnya hutan jati dapat menjadi sumber penghasilan perempuan di sela-sela menjalankan tugas domestiknya di rumah tangga. Waktu luang saat menanti anak pulang sekolah dan suami pulang bekerja dapat dimanfaatkan untuk memberdayakan diri dengan menghasilkan produk kreatif dan bernilai ekonomi. Dengan demikian, tidak hanya pengetahuan dan keterampilan perempuan yang meningkat, tapi ekonomi keluarga pun dapat meningkat.
\end{abstract}

Kata kunci: Pemberdayaan perempuan, Ecoprinting, Creative-Sociopreneurship

\section{INTRODUCTION}

\section{Situation Analysis}

Ngembat is a village located in Gondang, Mojokerto, East Java, Indonesia. Ngembat itself is divided into two sub-villages, Blentreng and Ngembat. This village is named Ngembat because the area lacks of water. Ngembat also has rich natural resources due to its place near the mountains, such as banana, cassava, corn, dragon fruit, and a local sweet potato called porang. In fact, these resources are Ngembat's strongest core points; they give benefits for the locals and a good potential for businesses. Ngembat also has a beautiful landscape and a perfect place for enjoying nature since its location is surrounded by teak forest and near mountain.

Most of Ngembat village area is teak forest, both government property or private. Although teak forests are filled, villagers cannot carelessly use teak trees for personal purposes, such as cutting down their trees. So that teak trees are left just like that to grow dense from year to year, without any of their initiative to use the leaves or stems for entrepreneurship or making a living. There are 1267 people in Ngembat Sub-Village, consisting of 410 families (LPPM UK Petra, 2019). Most of them work as farmers and housewives, only one person work for government and few build their own business. There 
are still low motivation for entrepreneurship since the people came from low-educated background. Income is generally low in this sub-village as majority of the people tend to become farmer than opening their own business. That caused the villagers to be very dependent on natural resources. Almost all women in Ngembat are unproductive and do not have their own income. Everything depends on the husband who works as a farm laborer and a builder. Everyday they are responsible for household chores and matters such as cooking and caring for children (or grandchildren). The free time available is used to gather with fellow housewives, just to chat. There were no initiatives from women in Ngembat sub-village to become entrepreneurs so they could support household income. Because they feel have not enough knowledge and skills. They feel insecure, low self-esteem, and feel unable to work because of the low level of education pursued. Knowing that, women in Ngembat content themselves with just being a housewife.
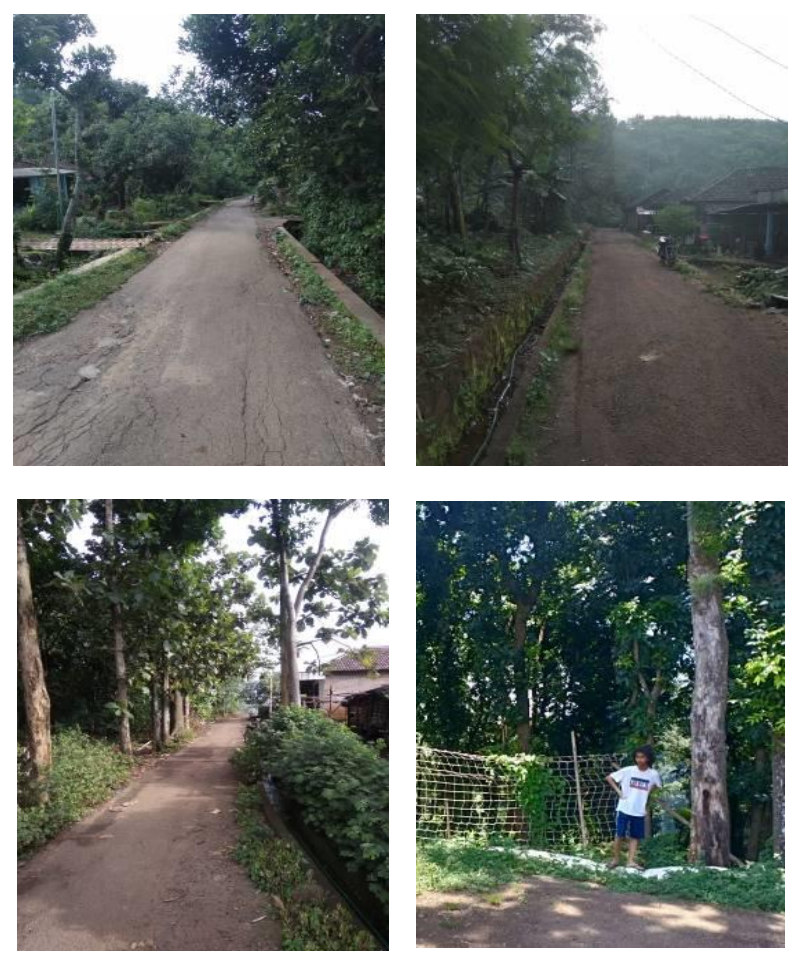

Image 1. Ngembat Sub-Village surrounded by teak forest

\section{Partner Problems}

From the field survey, the condition of the village's social, education, and economic are quite concerning. Ngembat villagers awareness of education are very poor so it needs to be increased. Fortunately, the facilities are sufficiently available like the human resources and abundant natural resources. Analysis of partner problems is obtained through SWOT analysis, as follows:

Strength: There are quite a number of women in Ngembat, both from adolescents to housewives.
Women in Ngembat have a lot of free time that can be used for more productive activities.

Weakness: The low level of education that has ever been taken. Most of the roles are housewives, do not make any income. Feeling inferior and not capable enough to start entrepreneurship. Feeling lacking the skills to start entrepreneurship. Lack of knowledge about the use of natural resources from the surrounding environment.

Opportunity: Abundant natural resources, especially teak trees. The desire to have their own income so they can live more prosperously. Willingness to learn new things. There is a savings and loan cooperative office from Mojokerto City that can support the provision of capital for entrepreneurship.

Community Outreach Program (COP) is a community empowerment program that has been held regularly at Petra Christian University. COP becomes a bridge for the implementation of theories learned by students in class. So that the knowledge and skills that have been learned can have a direct impact on improving the quality of people's lives.

DKV 4 subject emphasizes creative-sociopreneurship learning. This course prepares students to become scholars who focus on the creative industries, have critical thinking skills, market analysis skills, have the ability to develop innovative designs, create business opportunities, build and run new businesses in the face of global competition by raising local wisdom. For one semester, students are taught about creative thinking using eco printing techniques using teak leaves. The lecture is held to experiment with finding an innovation in eco printing that has the potential to become a superior commodity for the community. Students are also encouraged to interact directly in the community to share knowledge through service-learning methods. This course has an important role in universities to create creative entrepreneurs who are able to answer the challenges of the times. College graduates are not only absorbed by companies but can create jobs that can reduce unemployment so that strong community fundamentals are created.

Threat: Difficult access to information due to their minimal internet and communication networks. Road facilities are badly damaged so as to hamper enough travel to pick up raw materials in teak forests.

Based on the explanation, the partner's problem is the low productivity of women in Ngembat sub-village, even though in their environment there are abundant natural resources (teak trees) that can be used as raw materials for thier entrepreneurship. The low knowledge and skills possessed by the villagers have an impact on the high poverty rate in Ngembat sub-village. 
Considering the large number of women in Ngembat, the aim of this training is to empower women so that their knowledge and skills will increase. Women empowerment is carried out through ecoprint training activities made from teak leaves which are mostly obtained from forests around Ngembat sub-village. The purpose of this activity is to provide knowledge and improve skills on how to use teak leaves into creative products that have economic value.

\section{LITERATURE REVIEW}

\section{Women Empowerment}

The majority of women living in rural areas work in the agricultural sector. After working for a day managing farms in the homes of women, both mothers and young women, are still busy with their household chores. This causes women to not have the time to empower themselves. In addition, awareness to empower all potentials that are still very low is caused by many factors, among others: low levels of education, still having the mindset that women are naturally below men so all activities carried out are oriented to assist in domestic work and devoted his whole life to household and family work.

To place women's position equally with men, a process of improvement is needed in every way, including awareness to empower. Empowerment is a series of activities to strengthen the ability or empowerment of marginal groups in society, such as the poor, uneducated, and disabled, including women. Empowerment is oriented towards a better, more empowered, more prosperous, more independent and equal condition. The ultimate goal is to make the targeted community has the knowledge and ability to meet their needs independently, whether physical, economic, or social, such as having confidence, being able to convey aspirations, having a livelihood, being able to have an income, participating in social activities, and being independent in carrying out the tasks of everyday life (Ife, 2014: 59-60).

Women empowerment is the strengthening of women in various forms of social, economic and political life based on the relationship between personal freedom and the prevailing rules of society. Women empowerment should not be intended to force women to compete with men in the public sector in order to achieve a higher position, but should be done to encourage women (and also men) to create cooperation and synergies in harmony, both in the domestic and public sectors in achieving a safe and prosperous family and community order. Development of women's empowerment is carried out to support and accelerate the achievement of quality of life and equal partners of men and women, carried out through socialization/education and training activities for women engaged in all fields or sectors. The government and private companies (including educational institutions) strive to create a society that is empowered, productive and independent, because every citizen has the right to have a decent living not including women.

To be able to play a role in the development of women are required to have an independent attitude, in addition to have the attitudes that can appreciate all the potential they have. The profile of women in Indonesia at this time is still in a dilemmatic situation, this is because of one hand Indonesian women are required to play a role in all sectors, but still do not forget their nature as women, namely to become housewives. According to Loekman Soetrisna (1999: 62) the cause of the dilemmatic situation of Indonesian women is, first, that Indonesia is a pluralistic country in terms of ethnicity and culture. Secondly, the existence of pluralism makes an opinion that generalizes that Indonesian women from the beginning have a low position of men. Third, the dilemmatic situation currently faced by Indonesian women is the result of a process of interaction from various social and political factors that are developing in Indonesia.

The area of skill is still of particular interest for women, such as sewing, handicraft, making food/ cakes and several other types of home industries that are still relevant to women's domestic tasks. Women's involvement in these skills can enhance women's roles and increase women's insight in order to improve quality of their life.

\section{Ecoprinting}

The increased public awareness of preserving nature makes the trend of environmentally friendly lifestyles increasingly popular and spread widely to various business sectors. No exception to the trend of super fashion especially textile coloring. Lately ecoprinting techniques have been developed, namely fabric dyeing techniques that use natural materials.

As the name implies ecoprint from the word eco comes from the words ecosystem (nature) and print which means to print, batik is made by printing with materials found in the natural surroundings as cloth, dyes, and motif makers (Flint, 2011). The material used are in the form of leaves, flowers, stems and even branches. Unlike batik or stamp that have some stages using chemicals, ecoprint uses natural elements without synthetic or chemical ingredients. That's why this batik is very environmentally friendly and does not cause water, soil or air pollution later on.

Ecoprinting is the process of transferring colors, shapes and textures from natural materials to 
textile media (such as fabric or leather) through direct contact (Flint, 2008). These natural materials such as leaves and stems of plants that have pigments and are sensitive to heat, such as teak leaves, red klengkeng leaves, lanang leaves, jarak kepyar leaves, teruju, miyono, guava leaves, kesumba, and jinitri. Recommended textile media are those that have natural fibers, such as cotton, linen, burlap, leather, wool, and silk, because they are able to absorb colors well. The ecoprinting technique goes through a process of heating/ steaming for several hours to get the color, shape and texture according to the original material.

The step of making ecoprint begins with the process of the fabric or mordanting, soaking the fabric using alum water for at least 24 hours. The remaining alum water for soaking is not discarded, but it can be used to clean the bathroom and the color locking process. This mordanting process is useful for maintaining color and opening the fabric pores so that the color and patterns are printed perfectly. Before processing the color transfer, the leaves and stems of the plant that have been prepared are soaked in vinegar or tunjung water. Immersion is carried out for 15-20 minutes to remove the natural pigment.

Next, is the process of printing by stretching the squeezed cloth to half-wet, then the leaves and stems have been soaked in such a manner over the fabric. In order for the pigment to come out fully, it can be beaten with a hammer. The power of hitting should be controlled so that the leaves do not break and the color absorbs well on the fabric. In fact, even if not beaten with a hammer, it does not matter, as the leaves and cloth are rolled and tied very tightly. Once the cloth and leaves are rolled and tied the next stage is steaming for 2-3 hours. This steaming process is intended for the base color of the leaves and stems.

After the steaming process is complete, the fabric is left for 1 hour to 3 days, until the hot steam is completely gone. The cloth roll is opened and cleaned from the remnants of leaves attached to the fabric, then the patterns and colors are printed on the fabric. The last process is the locking of the colors, which is done by soaking the steaming cloth with alum water, so that the patterns and colors do not fade. After that the cloth is washed using lerak (special soap for washing batik cloth) and dried them in the sun.

The uniqueness of the ecoprinting technique lies in the end result that is always different in each process. Each process has unique patterns, colors and textures even though they are repeated in the same way and material. It is this surprise and uniqueness that makes ecoprinting fabric attractive and of high quality.

\section{Creative-Sociopreneurship}

The phenomenon of sociopreneur learning today starts from the condition of Indonesian people who are financially difficult. The number of unemployed has increased along with increasing global challenges. The presence of social and Christian values taught at Petra Christian University aims to encourage independence to the community through the knowledge and skills shared by lecturers and students. Sociopreneurship activities require participation from many parties to create a better life in the future.

Wiratmo (1996) in Muhammad Shohib (2013), states that entrepreneurship is the ability and willingness to take risks through investing and utilizing time and funds in running a business. According to Suryana (2003), entrepreneurship is an ability that requires creativity and innovation in creating and adding value to goods and services. Creative-sociopreneurship prioritizes aspects of entrepreneurship in the field of creative industries based on art and design, where aspects of human resources are the most important pillars for the sustainability of its business. Someone who is interested in the business world is required to have ideas and high creativity supported by the latest innovations so that sales and results are real. Today's competition has two choices: creative to survive or not create at all. For this reason, ideas and innovations are needed to continue to be able to develop businesses and build business networks.

DKV 4 subject that focuses on creative-sociopreneurship aims to develop and produce creative and innovative entrepreneurs, with a global perspective, and has the ability to develop and apply creative technology to advance market-based resilient businesses by raising local wisdom. In the end, students can make a real contribution to the welfare of society through community service, based on the application of science and skills

\section{Community Outreach Program (COP)}

Based on http://cop.petra.ac.id/, Community Outreach Program (COP) is an inter-discipline educational activity set to give a learning experience to the students by living in the community to give respond to the actual social life \& help the community development problems. This program is a part of the curricula for bachelor degree as well as the supporting medium to foster community development.

University Tridharma is the primary responsibility of every higher education institution in Indonesia. It consists of teaching, research, and devotion to the community. COP is an activity that integrates teaching, research and dedication to the community. Also included in the curriculum for undergraduate requirements. 
Referring to the research, COP participant students are encouraged to make observations, collect data, analyze and understand data about conditions and situations at the COP location. The COP location is placed in remote villages in the provinces of East Java and East Nusa Tenggara, in collaboration with the local government. Then, students discuss with their fellow students and their accompanying lecturers to solve problems that occur at the site by considering several alternatives based on the field of study. Each alternative solution must consider the environmental conditions and local potential. Through serving the community at COP, every student can apply science and art technology directly to provide concrete impacts and solutions for the community. In short, through COP students help the community in solving and dealing with problems that arise.

COP is expected to not only be a community service project, but also a two-way and continuous learning process. Students can apply their knowledge to meet the needs of the community and at the same time be able to learn empirical experiences from the community. COP participants came from various universities from several countries that are: South Korea: Dongseo University (DSU), South Korea, The Netherlands: INHOLLAND University, Hong Kong: Hong Kong Baptist University (HKBU) and Cung Chi College-The Chinese University of Hong Kong, Japan: International Christian University (ICU) and St. Andrew's University, India: Lady Doak College, Indonesia: HKBP NommensenMedan, Universitas Katolik Soegijapranata, Semarang, Universitas Sanata Dharma, Yogyakarta, Universitas Kristen Indonesia Paulus, Makassar, Universitas Kristen Palangkaraya, Palangkaraya, Universitas Kristen Krida Wacana, Jakarta and Universitas Katolik Widya Mandiri, Kupang.

\section{METHODOLOGY}

\section{Preparation of activity}
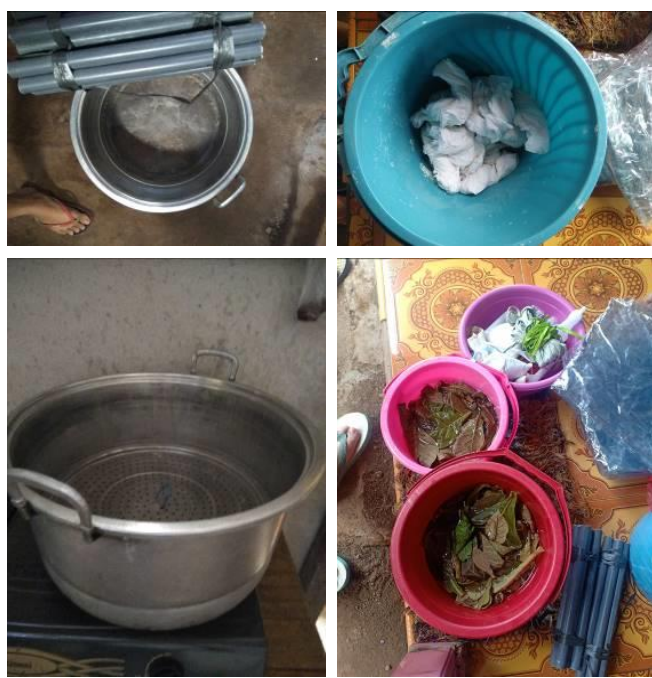

Image 2. Preparation: materials and equipment supported by villagers
This training activity focuses on aspects of developing creativity and increasing women's skills to be productive and independent. In the preparation stage, it is carried out through exploration, observation and interview activities to women who are targeted by the activity. Exploration and observation activities are useful for students and villagers to understand the characteristics of teak leaves which can be used for the ecoprint training. This exploration activity was carried out in a teak forest not far from where the villagers lived. Observations were made to find out the daily activities of women in Ngembat, to find out what they were doing during their free time. Interviews were conducted within a number of women, the village head and the sub-village head of Ngembat to find out about the problems faced and discuss alternative solutions. The village head and the subvillage head of Ngembat welcomed the training, because it was considered to be able to provide new knowledge and skills to women in the Ngembat subvillage. Previously, no such activity had been carried out. The sub-village head volunteered to help provide the materials and equipment needed during the training. As well as taking the initiative to invite and motivate villagers to participate.

\section{Implementation of Activity}

The training activities carried out for two days: the first day to shop for materials and equipment, to the teak forest to pick leaves and to soak cloth in alum water baths. The first day of activities focused on counseling about the understanding, materials, equipment and characteristics of the leaves used in ecoprinting. The second day focused on ecoprinting practicum. At least 20 women participated in this ecoprint training. The activity begins with soaking teak leaves that have been picked into 2 buckets containing alum water and tunjung water. Young teak leaves soaked for approximately 15 minutes. The fabric which had been soaked in alum water and soda ash a day before, squeezed it into a halfwet-half-dry condition. In this training a 50 x $120 \mathrm{~cm}$ cotton cloth is used, a common size to be used as a scarf. Then the fabric is laid for the top arranged teak leaves. Teak leaves soaked in vinegar water will produce maroon and purple colors. While teak leaves soaked in tunjung water will produce a blackish green color. The trainees were given the freedom to be creative in arranging the composition of the leaves on the fabric. After all the leaves have been arranged, the fabric is coated with plastic before being rolled up. The point is to avoid color leakage to unwanted areas. The layers of cloth, leaves and plastic are then rolled up with the help of pipes and tied tightly using string. So that the leaves that have been arranged do not shift during the steaming process. The steaming process takes approximately 2 hours. 

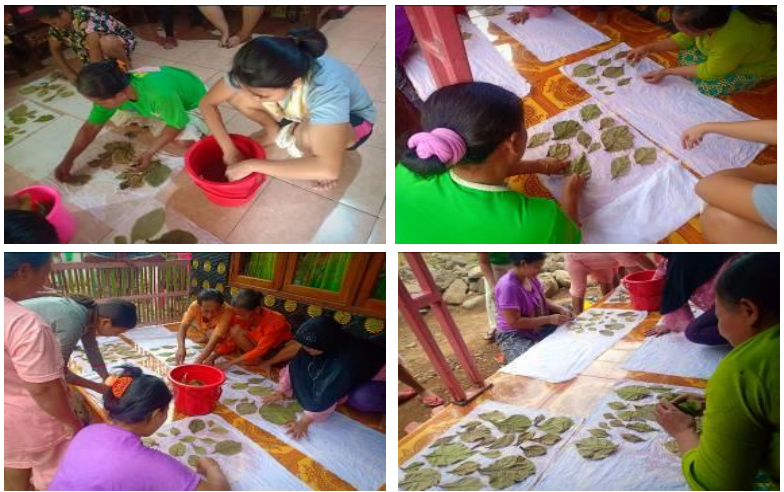

Image 3. Documentation of arranging teak leaves on fabric

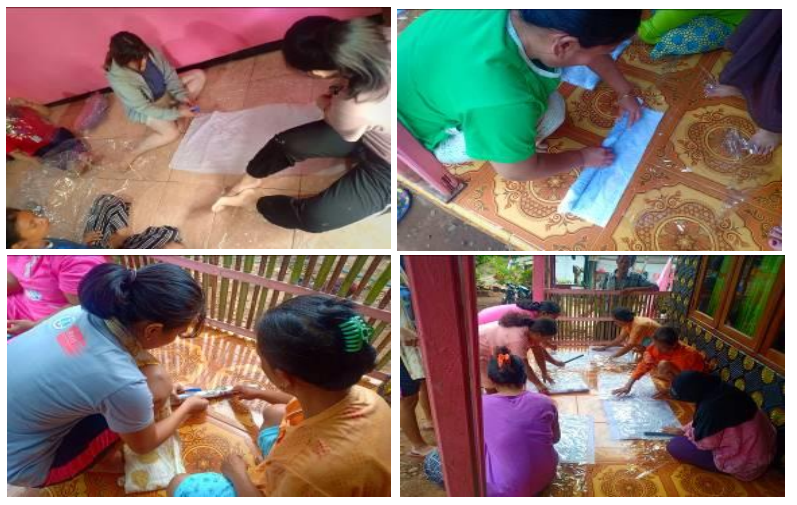

Image 4. Rolled fabric that has been arranged teak leaves in it with
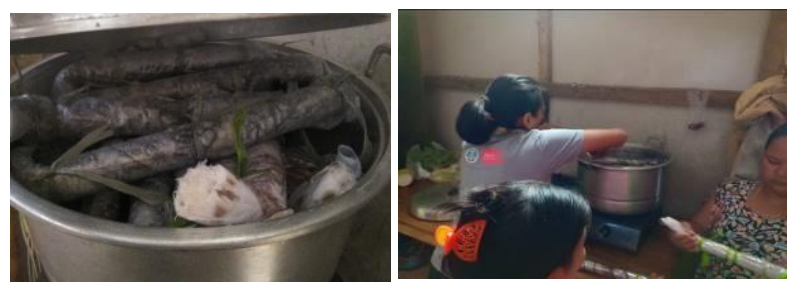

Image 5. Documentation of steaming the fabric and teak leaves process

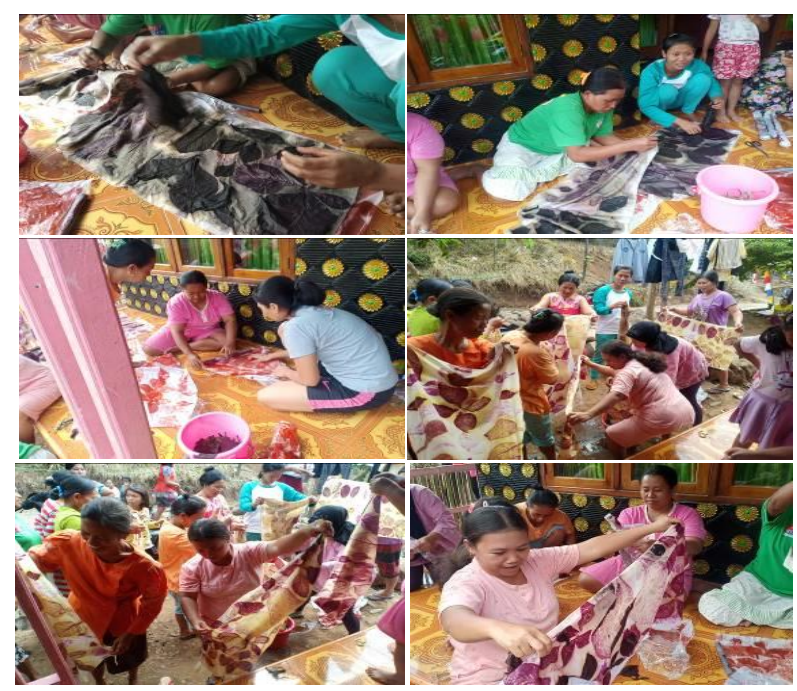

Image 6. Documentation of unroll the cloth, clean the remaining teak leaves and lock the color with alum water (Source: Ngembat group documentation)
The whole activities was carried out in the home of one of the villagers. Voluntarily, also providing her kitchen, lending pots and stoves to support the steaming process. While waiting for the steaming process, some of the trainees must return home to cook lunch for the family, take clothespins and pick up children from school. After the steaming, the trainees were enthusiastic about the final results of the ecoprint, they hoped the results would be satisfactory. After the rolled cloth has been removed separated from the plastic and the remaining leaves attached, the cloth is rinsed in alum water, this process is called fixation. Then they can be dried in the sun.

\section{DISCUSSION}

\section{Implementation and Result}

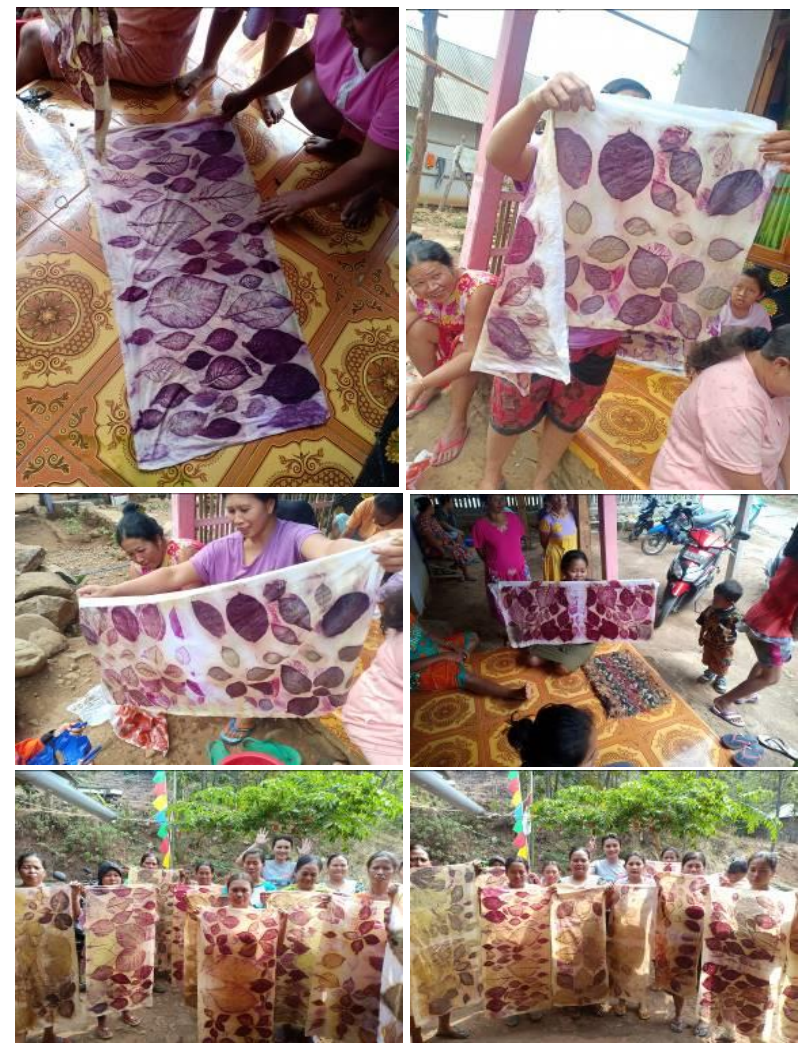

Image 7. The result of activities: Ecoprint Scarf

Previously, women in Ngembat had never received training like this. Most of the training that was held by the local government was only aimed at men, such as training in coffee milling, cassava processing and training related to other agriculture. Because men in Ngembat Sub-village are considered to be the backbone of the family that sustains the family's main income. Whereas training for women in Ngembat was limited to Posyandu on nutrition and child health. Training on the provision of entrepreneurship for women has never been held before. 
Because this is the first experience, some women in Ngembat sub-village feel hesitant to participate. They feel inferior and discouraged before trying. But because of the encouragement and motivation from the village chief, at least 20 women were willing to participate despite having to take the damaged roads to reach the training location. The results of this activity in the form of 20 sheets of cotton shawl ecoprint. Scarves with teak leaves motif in purple and maroon become the first products of women in Ngembat Sub-village. Knowing the good results, they appear satisfied, happy and have increased self-confidence.

\section{Impacts and Benefits from the Activity}

\section{Increased knowledge and skills of Ngembat Women}

Ngembat is surrounded by many teak forests. They did not know that teak leaves could be the raw material for natural dyes for textiles. They only know about the benefits of teak for furniture and home construction. And that means having to wait for a tree to be old enough to be cut down. So that for years the teak forests are left just like that to experience molt in the dry season and lush in the rainy season. They regretted their ignorance of the benefits of teak trees without having to cut them down. It turns out that the teak leaves that they see every day can be useful as natural coloring agents.

The necessary ingredients such as vinegar, alum and soda ash are easily obtained at the nearest market. Women in Ngembat sub-village previously only knew these materials for household needs, such as cooking and washing clothes. The materials that they often use at home can apparently be used for other things of economic value. The prices of the ingredients are relatively cheap for the villagers. They became enthusiastic to learn this ecoprint technique. The equipment also all women already have it at home, such as buckets, large pans, and stoves. No need to buy new equipment to start this entrepreneurship.

The day after the training activity, two women came to me and students to ask for more information about ecoprint. They are interested in learning by themselves, because there is a teak forest behind the house. Teak leaves can be obtained easily. To simplify the learning process, we took the initiative to make a simple infographic for them. The infographic describes the materials and equipment needed, as well as the step by step ecoprint process.

\section{Economic Increase of Ngembat Women}

During the first day of counseling, it was delivered that the ecoprint shawl or fabric was worth hundreds of thousands in big city boutiques and galleries. Even though the initial capital needed is not too high. Ingredients such as vinegar, alum and soda ash are quite cheap on the market. Some mothers even have it in their own kitchen. Equipment such as buckets, large pans and stoves are already available. Abundant teak leaves around the residence can be picked for free, because most are private property. Knowing the small capital ratio and large profits, women in Ngembat subvillage are enthusiastic to take part in this ecoprint training. They realize that household finances are very limited to starting a business, because it relies on the husband alone as a source of income. They hope that they can help support household finances, but limited knowledge and capital.

Through ecoprint training made from raw natural resources, it can improve the economy of women while at the same time being able to improve the welfare of families in Ngembat sub-village. So women who were helpless before, can become more empowered and independent.

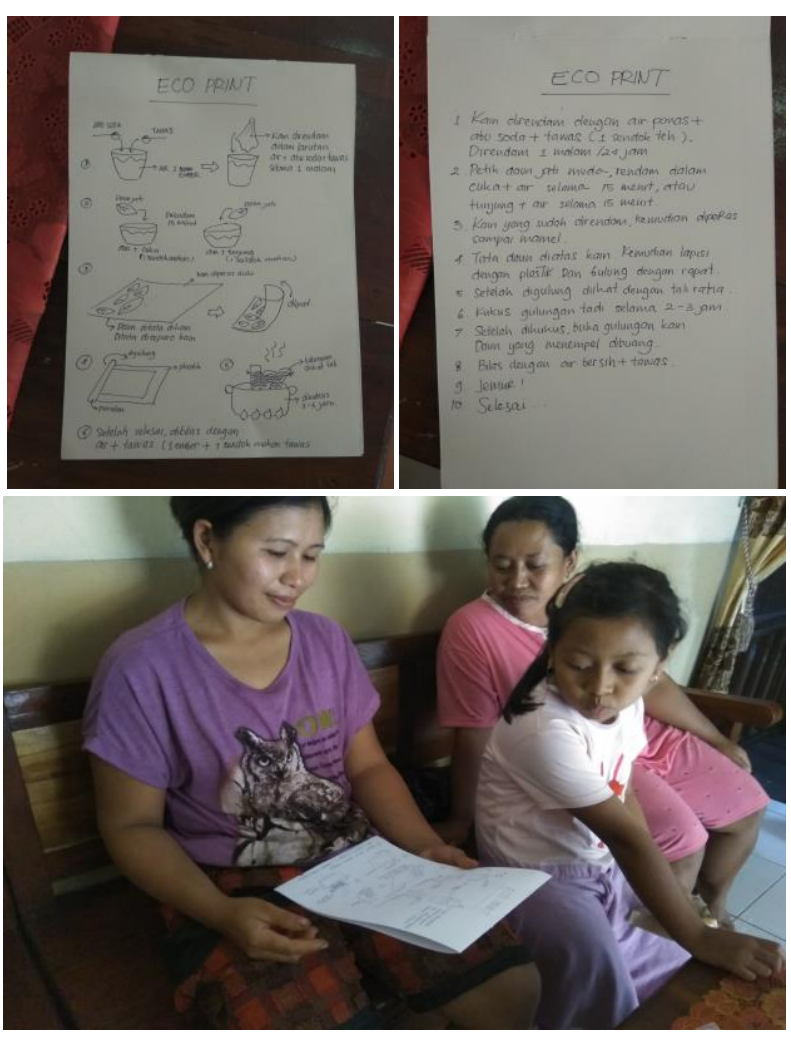

Image 8. Documentation of two women came to ask for more information about ecoprint and simple infographic about step by step ecoprint technic

\section{CONCLUSION}

Eco printing in DKV 4 subject studied in class or in the studio by students and lectures, can have a real impact on society. Especially Especially in communities that have very rich natural resources but lack knowledge and skills. Like people in Dusun Ngembat. 
Ecoprint training is the first training ever done by women in Ngembat sub-village. Previously training held by the local government was limited to the male group, which was considered the backbone of the household, as the main source of income. With livelihoods as farm laborers and builders, men must support their extended families. Women in Ngembat are powerless to help their husbands because they feel they have not enough knowledge and power, not confident due to their low education and limited capital to start an independent business. They only surrender and depend on the income of the husband. So that everyday they do only domestic activities, such as cooking, washing, taking care for their children (and or grandchildren). Leisure time is used to gather with neighbors to chat or take a nap. Women's free time in Ngembat Sub-village has not yet been utilized for a productive and beneficial activity.

The ecoprint training held during the Community Outreach Program (COP) aims to improve the knowledge and skills of women in Ngembat subvillage. That the natural resources that are around them can be utilized as products with high economic value. Abundant teak leaves due to the vast teak forests of Ngembat sub-village can be a source of women's income on the sidelines of carrying out their domestic duties in the household. Free time as long as waiting for children to come home from school and their husbands from work can be used to empower themselves by producing creative products with a high economic value. Thus, not only does women's knowledge and skills improve, but the family economy can also be improved.

\section{ACKNOWLEDGEMENT}

1. Universitas Kristen Petra, Surabaya.

2. Lembaga penelitian dan Pengabdian Masyarakat (LPPM) Universitas Kristen Petra.

3. Fakultas Seni dan Desain Universitas Kristen Petra, Program studi Desain Komunikasi Visual.

4. Kabupaten Mojokerto, Mojokerto.

5. Kepala Desa Ngembat, Mojokerto.

6. Kepala Ngembat sub-village, Mojokerto.

7. Warga dan PKK Ngembat sub-village.

\section{REFERENCES}

Flint, India. 2011. Second Skin. Millers Point. New South Wales: Murdoch Books Publisher

Flint, India. 2008. Eco Colour: Botanical Dyes for Beautiful Textiles. United States: Interweave Press Publisher.

Ife, Jim dan Tesoriero Frank. 2014. Alternatif Pengembangan Masyarakat di Era Globalisasi "Community development". Yogyakarta: Pustaka Pelajar.

Shohib, Muhammad. 2013. Adversity Quotient Dengan Minat Entrepreneurship. Vol. 01, No. 01, Januari 2013. ISSN: 2301-8267.

Soetrisno, Loekman. 1995. Menuju Masyarakat Partisipatif. Yogyakarta: Kanisius.

Suryana. 2003. Kewirausahaan: Pedoman praktis, kiat dan proses menuju sukses. Jakarta: Salemba empat.

Wiratmo, M. 1996. Pengantar Kewirausahaan. Yogyakarta. BPFE.

http://cop.petra.ac.id/ diakses 1 Agustus 2019.

Bapeda Kab. Mojokerto. 2016. Mojokerto Regency Medium-Term Development Plan (RPJMD) 2016-2021. 